\title{
The significance of the environment for energy utilization in the pig
}

\section{By W. H. Close, ARC Institute of Animal Physiology, Babraham, Cambridge $C B_{2}{ }_{4} A T$}

A concept which is basic to the consideration of an animal's energy exchange is that of thermal neutrality. Thermal neutrality is the zone of environmental temperature within which an animal's heat expenditure is constant and at a minimum, with corresponding maximum retention of dietary energy. The lower end of the zone of thermal neutrality is termed the lower critical temperature $\left(T_{c}\right)$, below which the animal must increase its heat production if body temperature is to be maintained at a constant level. If the animal is on a fixed energy intake this increase in heat production results in a diminution of energy retention and reduced growth.

The position of the thermally-neutral zone, and hence $T_{c}$, on the ambienttemperature scale is influenced by both nutritional and environmental factors. It is useful to know the extent to which temperatures below $T_{c}$ cause an increase in heat production because this indicates what reduction in growth is to be expected. It is also useful to know the partition of dietary energy into those components necessary for maintenance and thermoregulation and those associated with growth. These characteristics will be analysed in this paper in relation to those nutritional and environmental interactions of specific relevance to pig production.

\section{Plane of nutrition and critical temperature}

Within and above the zone of thermal neutrality there is no extra thermoregulatory heat demanded of the animal and the heat associated with the productive processes has to be dissipated. The higher the plane of nutrition, the higher is the mean rate of heat production. Below the zone of thermal neutrality part of the increased heat production associated with higher levels of feeding is used to compensate for some of the extra thermoregulatory heat demanded of the animal. The higher the level of feeding, the greater is the extent to which all the thermoregulatory heat requirement can be met by such heat production and this has the effect of lowering the animal's $T_{c}$.

This phenomenon in the pig has been reported by Close et al. (1971), Verstegen et al. (1973) and Close \& Mount (1978). For an individually-maintained $35 \mathrm{~kg}$ animal, Close \& Mount ( 1978 ) have calculated that at intakes between the fasting and ad lib. levels, $T_{c}$ falls by $\mathrm{I}^{\circ} / 20 \mathrm{I} \mathrm{kJ}$ per $\mathrm{kg}$ body-weight ${ }^{0.75}$ per $\mathrm{d}$ increase in metabolizable energy (ME) intake. This value varies, however, according to the body-weight of the animal, its group size and extent of thermal insulation. As the body-weight of individually-housed animals increases from 5 to 35 and $75 \mathrm{~kg}$, then the increase in ME intake per $\mathrm{I}^{\circ}$ fall in $T_{c}$ decreases from approximately 300 to I 70 and $140 \mathrm{~kJ} / \mathrm{kg}$ body-weight ${ }^{0.75}$ per d, respectively (Agricultural Research Council, 


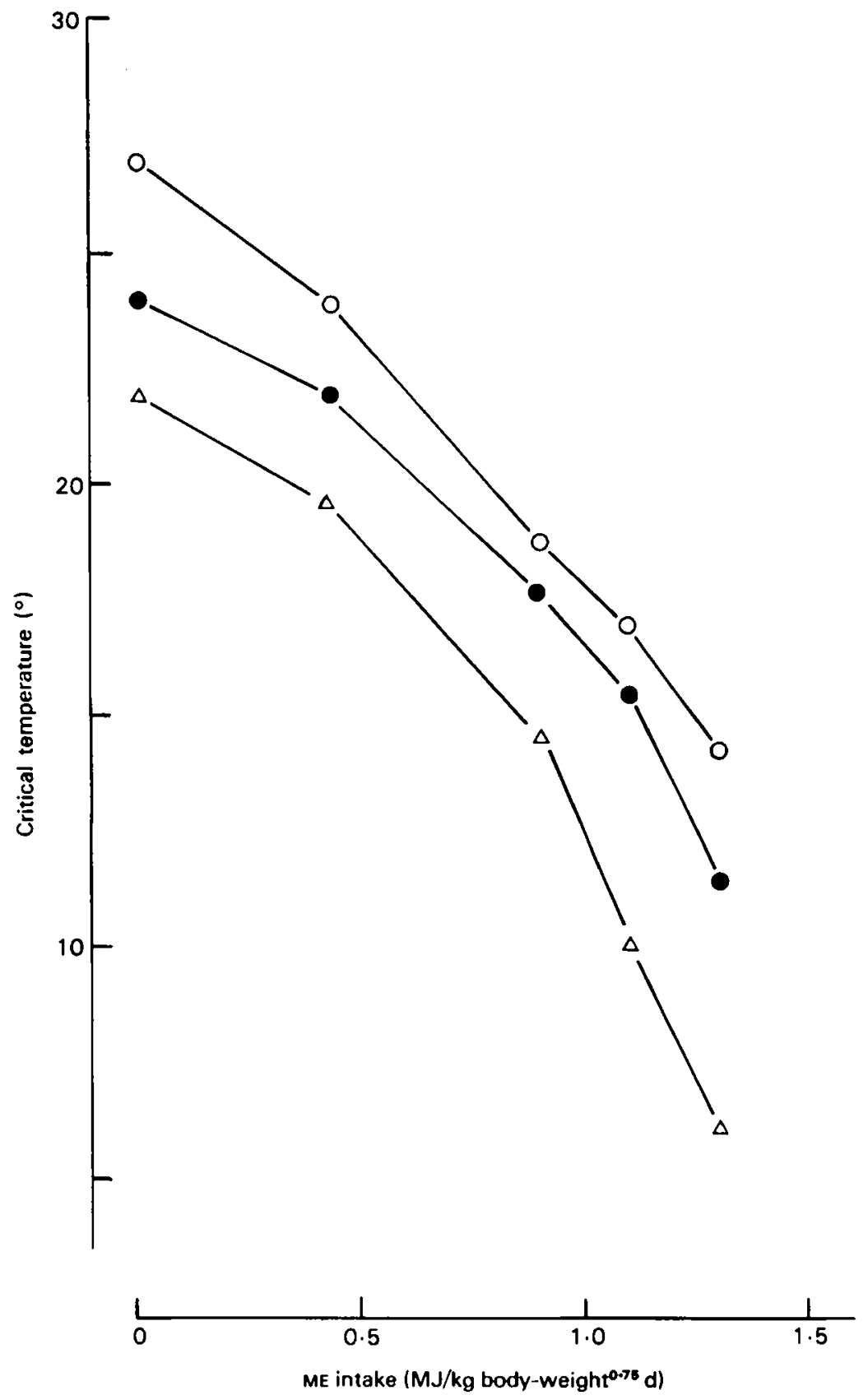

Fig. 1. The relation between critical temperature $\left({ }^{\circ}\right)$ and metabolizable energy (ME) intake $\left(\mathrm{MJ} / \mathrm{kg}\right.$ body-weight ${ }^{0.75}$ per d) for pigs housed in groups at 20,60 and $100 \mathrm{~kg}$ body-weight. $(0-0)$, 20; $(-)$ ), 60; $(\Delta-\Delta)$, $100 \mathrm{~kg}$ body-weight. 
1980). For groups of animals the increase would be 100 and $75 \mathrm{~kJ} / \mathrm{kg}$ bodyweight ${ }^{0.75}$ per $\mathrm{d}$ per $\mathrm{I}^{\circ}$ at mean body-weights of 35 and $75 \mathrm{~kg}$, respectively.

The extent to which the over-all thermal insulation of the animal influences the relation between ME intake and $T_{c}$ can be calculated from the values given by Holmes \& Close (1977) for thin and fat sows at different levels of feeding. Their results suggest that for thin sows the mean increase in ME intake required to reduce $T_{c}$ by I ${ }^{\circ}$ was $86 \mathrm{~kJ} / \mathrm{kg}$ body-weight ${ }^{0.75}$ per $\mathrm{d}$ whereas for fat sows it was $72 \mathrm{~kJ} / \mathrm{kg}$ body-weight ${ }^{0.75}$ per $\mathrm{d}$, that is, a decrease of $16 \%$.

For practical purposes it is necessary to have an indication of the relation between ME intake and $T_{c}$ and to determine how this changes with increase in body-weight of the animals. For this purpose Fig. I has been compiled from results on groups of animals from the experiments of Bond et al. (1952), Holmes \& Mount (1967), Verstegen (1971), Close et al. (1971) and Verstegen et al. (1973). Other environmental conditions such as changes in the rate of air movement, radiant temperature and floor insulation will influence the relation between $\mathrm{ME}$ intake and $T_{c}$ and, although not discussed in this paper, should be taken into account when assessing the optimum environmental conditions under different housing and management systems. The significance of these environmental variables and their effect on the $T_{c}$ of the animal have been discussed by Verstegen \& van der Hel (1974), Mount (1968, 1975, 1976), Holmes \& Close (1977), Verstegen et al. (1978) and Bruce \& Clark (1979).

\section{The efficiency of energy utilization}

The environment within which the animals are maintained determines the extent to which ME is utilized for maintenance and thermoregulation on the one hand and energy retention (ER) or growth on the other. At any given level of intake a reduction in the environmental temperature below $T_{c}$ leads to an increase in the energy requirement for maintenance $\left(\mathrm{ME}_{\mathrm{m}}\right)$ and a reduction in the energy available for growth (Close, 1978). The efficiency with which energy is utilized for growth will also change. It is important, however, to distinguish between gross efficiency $\left(k_{g}\right)$, that is, ER:ME intake, and net or partial efficiency $\left(k_{p}\right)$, that is, ER:energy available for production $\left(M E_{p}=M E-M E_{m}\right)$. At any given level of intake a reduction in environmental temperature leads to a reduction in $k_{g}$. However, similar efficiencies can be obtained by increasing the animal's $\mathrm{ME}$ intake at the lower temperatures. The results of Fuller \& Boyne (1972) and Close et al. (1978) indicate that the maximum $k_{g}$ obtainable is approximately 0.50 and this can be achieved over a wide range of environmental conditions. For example, from the results of Close et al. (1978), $k_{g}$ values within the range $0.47-0.49$ were obtained at temperatures between 10 and $25^{\circ}$, but the ME intake required was approximately $40 \%$ higher at $10^{\circ}, 1965$ compared to $1406 \mathrm{~kJ} / \mathrm{kg}$ body-weight ${ }^{0.75}$ per d. This indicates that a much larger proportion of the ME intake is required for the maintenance of the animals at the lower temperature.

Net or partial efficiency $\left(k_{p f}\right)$ relates to the utilization of the $M E$ intake above energy equilibrium, that is above the animal's maintenance energy requirement. 
Below $\mathrm{ME}_{\mathrm{m}}$ the efficiency is termed the efficiency of energy utilization for maintenance $\left(k_{\mathrm{m}}\right)$. The results of several investigations indicate that $k_{p f}$ increases with decrease in environmental temperature. Below $T_{c}$ part of the heat loss associated with protein and fat synthesis spares some of the extra thermoregulatory heat production so that $k_{p f}$ appears higher than at temperatures within or above the zone of thermal neutrality where there is no extra thermoregulatory heat production and where the heat associated with protein and fat synthesis has to be dissipated. $\boldsymbol{k}_{p f}$ changes within the range $\mathrm{I} \cdot 0-0.8$ below $T_{c}$ to $0.8-0.7$ within thermal neutrality and $0.7-0.6$ under warmer conditions (Close, 1978). If heat loss were completely independent of feeding level below $T_{c}$, then it follows that $k_{p j}$ should be $\mathrm{I}$. O. In practice, only the results of Verstegen $e t$ al. (1973) with groups of pigs at $8^{\circ}$ suggest this to be the situation. All other estimates below $T_{c}$ indicate values within the range 0.9-0.8 (Fuller $\&$ Boyne, 1972; Close, 1978), suggesting that heat production is dependent on feeding level below $T_{c}$, although to a lesser extent than within the zone of thermal neutrality where many estimates of $k_{p f}$ within the range $0.75-0.65$ have been proposed (Brierem, 1939; Bowland et al. 1970; Close et al. 1973; Holmes, 1974; Sharma et al. 1971; Thorbek, I975). Under cold conditions it is possible that there may be variations in the animal's $T_{c}$ within the $24 \mathrm{~h}$ period, particularly after feeding, where the effects of the heat increment may be to depress $T_{c}$, with the result that the mean daily $k$ value is less than $\mathrm{I} \cdot 0$. However, the results indicate that the relation between ER and ME intake is curvilinear, that the extent of curvilinearity depends upon feeding level and, as feeding level is an important factor determining $T_{c}$, that $k_{p f}$ changes in relation to $T_{c}$.

\section{Chemical composition of body-weight gain}

Although it is interesting and useful for predictive purposes to compare the rate and efficiency with which ER changes in relation to the animal's $T c$, it is also important for practical reasons to measure the changes in the rate of body-weight gain and the composition of that gain as protein, fat and water. There is now sufficient evidence to suggest that protein retention is less seriously affected by environmental temperature than fat deposition. A number of estimates have been proposed as to the extent to which protein retention decreases per unit decrease in temperature. These vary within the range -0.71 to $+2.80 \mathrm{~kJ} / \mathrm{kg}$ body-weight ${ }^{0.75}$ per $d$ per $1^{\circ}$ change in temperature (Fuller \& Boyne, 1971; Verstegen et al. 1973; Gray \& McCracken, 1974; Close et al. 1978; Phillips et al. 1979). These variations in the rate at which protein retention changes may be attributed to differences associated with the breed of the animal, its body-weight, the level of feeding and the concentration, digestibility and availability of the protein in the food. Fat deposition, on the other hand, is more severely influenced by environmental temperature, decreasing between 6.7 and $17.7 \mathrm{~kJ} / \mathrm{kg}$ body-weight ${ }^{0.75}$ per $\mathrm{d}$ per $\mathrm{I}^{\circ}$ decrease in environmental temperature (Verstegen et al. 1973; Gray \& McCracken, 1974; Close et al. 1978; Phillips et al. 1979). The rate at which protein and fat changes also depends upon the level of feeding and Close $e t$ al. 
(1978) have calculated the temperature equivalence of these tissues in terms of food intake. The reductions in protein and fat as a result of a $I^{\circ}$ decrease in environmental temperature below $15^{\circ}$ were equivalent to a 4 and $28 \mathrm{~g}$ reduction in food intake respectively. The corresponding value for body-weight gain was $20 \mathrm{~g}$. The temperature-dependent change in fat was thus greater than those for protein and body-weight gain.

These variations in the protein and fat gains of the animals reflect changes in carcase composition. On the basis that fat deposition is more severely affected than protein deposition, it may be concluded that exposure to cold environments results in leaner carcases. When measurements of back fat thickness were taken as the indicator, the results of Sugahara et al. (1970), Weaver \& Ingram (1969), Holmes (1971) and Verstegen et al. (1978) imply a reduction in fat content while Sørensen (1962) reported an increase and Holme \& Coey (1967) found little difference between the different temperature treatments. However, the levels of feeding employed in these experiments may have contributed to the different interpretations, as indicated by Fuller \& Boyne (1971).

The greater reduction in fat, relative to protein deposition, suggests that the lean (protein + water):fat value will be increased under cold conditions. Comberg et al. (1971, 1972) and Verstegen et al. (1978) have, however, indicated that the lean:fat value decreases under cold conditions as a result of the reduction in the water content of the lean gain. It is not known to what extent the water content per se is influenced by the feeding level of the animals and, by implication, the rate of gain. The chemical composition of the gain in body-weight of the $35 \mathrm{~kg}$ pig has therefore been calculated from the results of Close \& Mount (1978) and Close et al. $(1978)$ at similar body-weight gains both below $\left(10^{\circ}\right)$ and at the critical temperature. The methodology, derivation and results of these calculations are given in Tables $I$ and 2. These show that, in all instances, the increased feeding

Table I. Calculated rates of metabolizable energy intake (ME; $\mathrm{kJ} / \mathrm{kg}$ body-weight $t^{0.75}$ per $\left.d\right)$ required to maintain different growth rates $(\Delta \mathrm{W}$; $\mathrm{g} / \mathrm{kg}$ body-weight $\mathrm{t}^{0.75} \mathrm{per} \mathrm{d}$ ) in the $35 \mathrm{~kg}$ pig at an environmental temperature of $10^{\circ}$ $\left(\mathrm{ME}_{10}\right)$ compared with that at the critical temperature $\left(\mathrm{T}_{\mathrm{c}} ; \mathrm{ME}_{\mathrm{C}}\right)$; also the rate of increase of $\mathrm{ME} / \mathrm{r}^{\circ}$ below $\mathrm{T}_{\mathrm{c}}\left(\frac{\Delta_{\mathrm{ME}}}{\Delta \mathrm{T}}\right)$

\begin{tabular}{|c|c|c|c|c|}
\hline$\Delta W$ & $\mathrm{ME}_{10}{ }^{\circ}$ & $\mathbf{M E}_{c} \dagger$ & $T_{c} \ddagger$ & $\Delta \mathrm{ME} / \Delta T$ \\
\hline 20 & $95^{\circ}$ & 729 & $21 \cdot 4$ & 19.4 \\
\hline 30 & 1132 & 947 & $20 \cdot 3$ & 18.0 \\
\hline 40 & $133^{6}$ & II9I & 19.1 & 15.9 \\
\hline $5^{\circ}$ & 1569 & 1463 & 17.8 & 13.6 \\
\hline 60 & $18_{52}$ & 1787 & $16 \cdot I$ & 10.7 \\
\hline
\end{tabular}

- $M E_{10}$ calculated from equation no. 4 of Close et al. (1978) when $T=10^{\circ}$.

$\dagger_{M E_{c}}$ calculated from the equation $\triangle W=-25.2 \mathrm{I}+0.010 \mathrm{ME}-0.00000 \mathrm{I} \mathrm{ME}^{2}$ which was derived from equation no. 4 of Close et al. (1978) by substituting for $T$ the relationship given below.

$\ddagger T_{c}$ calculated from the equation $T_{c}=-0.00498 \mathrm{ME}+25.04$ which was derived from Table 2 of Close \& Mount (1978). 
Table 2. Calculated rates $\left(\mathrm{g} / \mathrm{kg}\right.$ body-weight $t^{0.75}$ per $\left.\mathrm{d}\right)$ of protein $(\mathrm{P})$, fat $(\mathrm{F})$ and water $(\mathrm{A})$ deposition in the $35 \mathrm{~kg}$ pig at different growth rates $(\Delta \mathrm{W} ; \mathrm{g} / \mathrm{kg}$ body-weight ${ }^{0.75}$ per $\left.d\right)$ at environmental temperatures of $10^{\circ}\left(\mathrm{T}_{10}\right)$ and the critical temperature $\left(\mathrm{T}_{\mathrm{c}}\right) ;$ also lean $(\mathrm{L}=\mathrm{P}+\mathrm{W}): \mathrm{F}\left(\frac{\mathrm{L}}{\mathrm{F}}\right)$

\begin{tabular}{|c|c|c|c|c|c|c|c|c|}
\hline \multirow[b]{2}{*}{$\Delta W$} & \multicolumn{4}{|c|}{$T_{10}$} & \multicolumn{4}{|c|}{$T_{c}$} \\
\hline & $P^{\star}$ & $F \dagger$ & $A \ddagger$ & $\frac{L}{x}$ & $P^{\bullet}$ & $F_{!}^{+}$ & $A_{+}^{+}$ & $\frac{L}{F}$ \\
\hline 20 & $3 \cdot 7^{2}$ & $2 \cdot 26$ & 12.02 & 6.96 & $2 \cdot 78$ & 2.86 & $12 \cdot 3^{6}$ & $5 \cdot 29$ \\
\hline 30 & 4.94 & $5 \cdot 14$ & 16.92 & $4 \cdot 25$ & 4.04 & 5.90 & 17.06 & $3 \cdot 5^{8}$ \\
\hline 40 & $6 \cdot 30$ & $8 \cdot 35$ & $21 \cdot 35$ & $3 \cdot 3 \mathrm{I}$ & $5 \cdot 4^{6}$ & $9 \cdot 26$ & $2 \mathrm{I} \cdot 28$ & $2 \cdot 89$ \\
\hline 50 & 7.86 & 12.04 & $25 \cdot 10$ & $2 \cdot 74$ & $7 \cdot 10$ & 13.01 & $24 \cdot 89$ & $2 \cdot 4^{6}$ \\
\hline 60 & $9 \cdot 75$ & 16.50 & $27 \cdot 74$ & $2 \cdot 27$ & 9.13 & 17.53 & $27 \cdot 34$ & 2.08 \\
\hline
\end{tabular}

"Calculated from equation no. I of Close et al. (1978) assuming an energy value of $23.8 \mathrm{~kJ} / \mathrm{g}$ (Brouwer, 1965).

+ Calculated on a kJ/kg body-weight ${ }^{0.75}$ per $\mathrm{d}$ basis from the equation, $F=-878 \cdot 0+0.694 \mathrm{ME}$ $+45.54 T-0.8516 T^{2}-0.006 \mathrm{I} 6 \mathrm{ME} \times T$ derived from Table I of Close et al. (I978). Calculated on a $\mathrm{g} / \mathrm{kg}$ body-weight ${ }^{0.75}$ per $\mathrm{d}$ basis assuming an energy value of $39.8 \mathrm{~kJ} / \mathrm{g}$ (Brouwer, 1965 ).

$\ddagger$ Calculated on the basis that $0.9 \Delta W=P+F+A$ (Close, 1970; Verstegen et al. 1973).

level necessary to maintain growth rate at $10^{\circ}$ enhances protein but not fat deposition. In addition, the water content of the body-weight gain at $10^{\circ}$ is slightly reduced at the lower but increased at the higher growth rates. The reduction in fat deposition was greater than the decrease in water deposition at the lower rates of gain at $10^{\circ}$ and, in association with the increase in protein deposition, resulted in higher lean:fat values at each rate of gain. However, the effect was diminished as rate of gain increased. These calculations are appropriate to young growing animals depositing protein and fat simultaneously. For more mature animals, where fat deposition is predominant, the effect may be less. The benefit to be derived from increasing food allocation at temperatues below $T_{c}$ appears, therefore, not only to maintain growth rates but also to promote a more desirable carcase with more lean and less fat content. Whether this is an economic proposition depends upon the prevailing economic circumstances.

\section{Future perspectives}

Feeding costs account for a very large proportion of the total costs of pig production. Optimum utilization of food will only be obtained under ideal environmental conditions and it is, therefore, important that the environmental requirements be accurately determined at all stages of production. Bearing in mind the diversity of husbandry and management systems, the general requirement is to determine the range of environments and nutrition which allow maximum efficiency in the utilization of food. This paper has described the significance of food intake and its effect upon the animal's $T_{c}$ and productive traits under precisely-controlled environmental conditions. When the environmental conditions change, for example, air temperature, radiant temperature, air movement, floor insulation, the optimum temperature for production changes and 
this has direct consequences on both the rate and efficiency of energy utilization. It is important, therefore, to assess the thermal environment either in relation to the animal's $T_{c}$ or an equivalent temperature, that is the temperature of a standardized environment that would have the same effect on the animal's metabolism. If the environmental conditions were then calculated as falling below the optimal, steps could be taken to improve them by the provision of supplementary heating, structural alterations to the building or by increasing the animal's food allocation, the latter having the effect of lowering the $T_{c}$ to that of the prevailing environmental conditions.

\section{REFERENCES}

Agricultural Research Council (1980). The Nutrient Requirement of Pigs (In the Press).

Bond, T. E., Kelly, C. F. \& Heitman, H. (1952). Agric. Engng 33, 148.

Bowland, J. D., Bickel, H., Pfirter, H. P., Wenk, C. P. \& Schürch, A. (1970). F. Anim. Sci. 31, 494.

Brierem, K. (1939). Tieremähr. II, 487.

Brouwer, G. (1965). Publs Eur. Ass. Anim. Prod. no. II, p. 44I.

Bruce, J. M. \& Clark, J. J. (1979). Anim. Prod. 28, 353.

Close, W. H. (1970). Nutrition-environmental interactions of growing pigs. PhD Thesis, The Queen's University of Belfast.

Close, W. H. (1978). Br. Y. Nutr. 40, 433 .

Close, W. H. \& Mount, L. E. (1978). Br. F. Nutr. 40, 413.

Close, W. H., Mount, L. E. \& Brown, D. (1978). Br. F. Nutr. 40, 423.

Close, W. H., Mount, L. E. \& Start, I. B. (1971). Anim. Prod. 13, 285.

Close, W. H., Verstegen, M. W. A. \& Mount, L. E. (1973). Proc. Nutr. Soc. 32, 72A.

Comberg, G., Stephan, E. \& Späth, H. (1971). Züchtungskunde 43, 225.

Comberg, G., Stephan, E. \& Späth, H. (1972). Züchtungskunde 44, 402.

Fuller, M. F. \& Boyne, A. W. (1971). Br. J. Nutr. 25, 259.

Fuller, M. F. \& Boyne, A. W. (1972). Br. F. Nutr. 28, 373.

Gray, R. \& McCracken, K. J. (1974). Publs Eur. Ass. Anim. Prod. no. 14, p. 16 1.

Holme, D. W. \& Coey, W. E. (1967). Anim. Prod. 9, 209.

Holmes, C. W. (1971). Anim. Prod. 13, 521.

Holmes, C. W. (1974). Anim. Prod. 19, 21 I.

Holmes, C. W. \& Close, W. H. (1977). In Nutrition and the Climatic Environment, p. $5 \mathrm{r}$. [W. Haresign, H. Swan and D. Lewis, editors]. London: Butterworths.

Holmes, C. W. \& Mount, L. E. (1967). Anim. Prod. 9, 435.

Mount, L. E. (1968). The Climatic Physiology of the Pig. London: Edward Arnold.

Mount, L. E. (1975). Livest. Prod. Sci. 2, 381 .

Mount, L. E. (1976). Proc. Nutr. Soc. 35, 81 .

Phillips, P. A., Young, B. A., McQuitty, J. B. \& Hardin, R. T. (1979). Paper no. 79-4002 presented at the 1979 Summer meeting of $A S A E$ and CSAE (June, 1979).

Sharma, V. D., Young, L. G. \& Smith, G. C. (1971). Can. F. Anim. Sci. 51, 761.

Sørensen, P. H. (1962). In Nutrition of Pigs and Poultry, p. 88. [J. T. Morgan and D. Lewis, editors]. London: Butterworths.

Sugahara, M., Baker, D. H., Harmon, B. G. \& Jensen, A. H. (1970). F. Anim. Sci. 31, 59.

Thorbek, G. (1975). Beretn. Forseglab no. 424.

Verstegen, M. W. A. (1971). Meded. LangbHogesch., Wageningen pp. 71-72.

Verstegen, M. W. A., Brascamp, E. W. \& van der Hel, W. (1978). Can. J. Anim. Sci. 58, I.

Verstegen, M. W. A., Close, W. H., Start, I. B. \& Mount, L. E. (1973). Br. F. Nutr. 30, 2 I.

Verstegen, M. W. A. \& van der Hel, W. (1974). Anim. Prod. 18, I.

Weaver, M. E. \& Ingram, D. L. (I969). Ecology 50, 710. 